\title{
Analysis of Chromosome Aberrations and Sister Chromatid Exchanges in Peripheral Blood Lymphocytes of Newborns after Vitamin $K$ Prophylaxis at Birth
}

\author{
MARLIES CORNELISSEN, DOMINIQUE SMEETS, GERARD MERKX, RONNEY DE ABREU, \\ LOUIS KOLLEE, AND LEO MONNENS \\ Departments of Pediatrics and Human Genetics, University Hospital Nijmegen, Nijmegen, The Netherlands
}

\begin{abstract}
In many countries vitamin $K$ prophylaxis at birth is recommended to prevent bleeding in infants due to vitamin $\mathrm{K}$ deficiency. Because the incidence of clinical vitamin $K$ deficiency is very low, such a vitamin $K$ administration should be completely safe. However, an increase in sister chromatid exchanges in lymphocytes of fetal sheep $24 \mathrm{~h}$ after injection of vitamin $K_{1}$ has been reported. Therefore, a study concerning genotoxicity of vitamin $K_{1}$ in man was conducted. Sister chromatid exchanges and chromosome aberrations were analyzed in peripheral blood lymphocytes of six newborns $24 \mathrm{~h}$ after intramuscular administration of $1 \mathrm{mg}$ vitamin $K_{1}$ and in six control neonates. The mean number of sister chromatid exchanges per metaphase in the vitamin $K$ group was $8.88 \pm 1.22$ as compared with $9.05 \pm 1.14$ in the control group (NS). The mean number of chromosome aberrations per 100 mitoses was $3.00 \pm 2.61$ in the vitamin $K$ group and $2.50 \pm 1.87$ in the control group (NS). Vitamin $K_{1}$ plasma concentrations ranged from 115 to $1150 \mathrm{ng} / \mathrm{mL}\left(255\right.$ to $\left.2555 \times 10^{-9} \mathrm{M}\right)$ in the supplemented group, a 5000-fold rise as compared with the control group $(p<0.01)$. We did not find any evidence for genetic toxicity due to the administration of 1 mg vitamin $\mathrm{K}_{1}$ intramuscularly to the newborn child. (Pediatr Res 30: 550-553, 1991)
\end{abstract}

\section{Abbreviations}

SCE, sister chromatid exchanges

CA, chromosome aberrations

BrdU, bromodeoxyuridine

The problem of bleeding in infants due to vitamin $\mathrm{K}$ deficiency has been recognized worldwide. In many countries vitamin $\mathrm{K}$ prophylaxis at birth is recommended to prevent this hazard. Introduction of such a prophylaxis appeared to have spectacular results on the incidence of this so-called Haemorrhagic Disease of the Newborn (1). Because the incidence of clinical vitamin $\mathrm{K}$ deficiency is very low, this vitamin $\mathrm{K}$ supplementation should be completely safe. However, in 1987, Israels et al. (2) reported a dose-dependent increase of the frequency of SCE in lymphocytes after in vitro exposure to vitamin $\mathrm{K}_{1}$. In vivo exposure, tested in five fetal sheep given $1 \mathrm{mg}$ of vitamin $\mathrm{K}_{1}$ i.v., also resulted in an increase in SCE $24 \mathrm{~h}$ after injection. SCE represent

Received March 13, 1991; accepted July 5, 1991.

Correspondence and reprint requests: Marlies Cornelissen, M.D., Department of Pediatrics, University Hospital Nijmegen, P.O. Box 9101, NL-6500 HB Nijmegen, The Netherlands.

Supported by the Dutch "Praeventiefonds." interchanges of DNA at apparently homologous chromosomal sites after replication. These exchanges presumably involve DNA breakage and reunion. Although there is no perfect agreement between the ability of a compound to produce SCE and its mutagenicity or carcinogenicity, there is a high degree of correlation (3). Israels et al. (2) postulated that the relative vitamin $\mathrm{K}$ deficient state of the newborn may in fact play a role in the protection of the fetus in utero by reducing the risk of mutagenic events during this period of rapid cell proliferation. The question arises whether the results of the study of Israels et al. indicate a genotoxic or carcinogenic risk to man, specifically when the vitamin is administered during early life. Moreover, Golding et al. (4) reported a statistical association between childhood cancer and vitamin $\mathrm{K}$ administration (among other drugs in the 1st wk of life). This association was found unexpectedly and fitted no prior hypothesis. The need for further research was stressed by the authors. To our knowledge, cytogenetic studies concerning genotoxicity of vitamin $K_{1}$ in man have as yet not been performed.

Apart from SCE assays, another way of testing for cytogenetic mutagenicity is to analyze CA. CA reflect damage of the chromosome- or chromatid-type and can be observed as breaks, acentric fragments, minutes, ring chromosomes, and gaps. Gaps are defined as regions in the chromatid structure that are achromatic, thus, the chromosome structure is not really discontinued (5). Because CA and SCE are two different cytogenetic end points of mutagenic action, they are complementary (6). Neither CA nor SCE have been studied before in human neonates exposed to vitamin $\mathrm{K}_{1}$.

The aim of this case-controlled clinical trial is to determine whether the administration of $1 \mathrm{mg}$ vitamin $\mathrm{K}_{1}$ intramuscularly after birth influences the occurrence of SCE and CA in cultured peripheral blood lymphocytes.

\section{MATERIALS AND METHODS}

The study was approved by the local medical ethical committee. Informed consent was obtained from the parents. Twelve healthy breast-fed newborns, delivered in our hospital, were recruited for this study. Selection criteria were delivery at term (37-42 wk), birth weight over $2500 \mathrm{~g}$, and Apgar score at $5 \mathrm{~min}$ of seven or more. The mother could not be on a special diet, smoke, abuse alcohol, or take any medication during the last month of pregnancy, except for iron or folic acid. Arterial cord blood $\mathrm{pH}$, mode of delivery, and medication of the mother during labor were recorded. All infants had an arterial cord blood $\mathrm{pH}$ over 7.24, except for subject 7, who had a pH of 7.17. All children were delivered vaginally, except for subject 1 , who was born by cesarean section. In two cases oxytocin was given to the mother during labor (subjects 3 and 11). 
The infants were randomly divided into two groups; six received $1 \mathrm{mg}$ vitamin $\mathrm{K}_{1}$ (Konakion; Hoffman-La Roche, Basel, Switzerland) intramuscularly, the other six received no medication. Some characteristics of the neonates are given in Table 1. No item differed significantly between the groups. After $24 \mathrm{~h}, 5$ $\mathrm{mL}$ of blood were drawn by aseptic venipuncture: $2 \mathrm{~mL}$ of heparinized blood and approximately $3 \mathrm{~mL}$ of blood with no additive. The latter was kept in the dark immediately after sampling, centrifugated $(3000 \times g$ for $5 \mathrm{~min})$, and stored at $-20^{\circ} \mathrm{C}$ until vitamin $\mathrm{K}_{1}$ determination. All samples were coded to provide blind cytogenetic analysis.

Vitamin $K_{1}$. Vitamin $\mathrm{K}_{1}$ was measured in 1-mL serum samples by a two-step HPLC procedure, according to the method of Lambert et al. (7, 8). A few modifications were applied. The assays were performed with two Spectra Physics SP8800 systems (Spectra Physics, Santa Clara, CA) equipped with Rheodyne 7125 manual injectors (Rheodyne, Cotati, CA), with $100 \mu \mathrm{L}$ sample loops. Vitamin $\mathrm{K}_{1(25)}$ was used as an internal standard. The first HPLC step was used for preseparation of vitamin $\mathrm{K}_{1}$ and $\mathrm{K}_{1(25)}$ on a microspher-Si column (Chrompack, Middelburg, The Netherlands). The locations of vitamin $\mathrm{K}_{1}$ and internal standard were detected with a variable wavelength detector model 770 (Spectra Physics) set at $248 \mathrm{~nm}$. Final separation and quantitation were performed during the second HPLC step, using a microspher-C18 column (Chrompack) for separation and postcolumn chemical reduction with tetramethylammoniumoctahydridotriborate for fluorescence detection $\left(\lambda_{\text {ex }}=325 \mathrm{~nm}\right.$, $\lambda_{\text {em }}=450 \mathrm{~nm}$ ) with a Waters 470 fluorescence detector (Waters Associates, Millipore Corp., Milford, MA). Concentrations were calculated from relative peak heights of vitamin $\mathrm{K}_{1}$ versus known amounts of internal standard. The lower limit of detection was $0.045 \mathrm{ng} / \mathrm{mL}$; however, the detection limit was dependent on the recovery of internal standard and the amount of serum extracted.

Cytogenetics. Peripheral lymphocyte cultures were initiated within $2 \mathrm{~h}$ after blood collection. For each culture two containers with medium (8 mL RPMI 1640 medium, supplemented with $15 \%$ FCS, heparin, phytohemagglutinin, penicillin, and streptomycin) were each supplied with $0.2 \mathrm{~mL}$ neonatal whole blood. From all infants two cultures were set up: one with and the other without $\mathrm{BrdU}$ (final concentration $10 \mu \mathrm{g} / \mathrm{mL}$ ). BrdU was present in the medium during the whole culture period. All cultures were grown in the dark at $37^{\circ} \mathrm{C}$ for exactly $72 \mathrm{~h}$. Colcemid (final concentration $0.2 \mu \mathrm{g} / \mathrm{mL}$ ) was added $90 \mathrm{~min}$ before harvesting. Chromosome spreads were made according to routine procedures. The standard cultures without BrdU were applied for aberration screening by one technician. From every child 100 mitoses were studied after conventional Giemsa staining and all $\mathrm{CA}$ were recorded and photographed. The cultures with BrdU were used for SCE studies. From every infant 25 complete mitoses were photographed in fluorescence microscopy after the chromosomes had been stained with acridine orange (9). In this way the number of SCE could easily be counted from the photograph.

For statistical evaluation the unpaired $t$ test was applied for study-population characteristics, SCE, and CA results. Vitamin $\mathrm{K}_{1}$ concentrations were compared by Wilcoxon's two-sample test. All values are given as means $\pm \mathrm{SD}$.

Table 1. Study population characteristics (mean $\pm S D$ )

\begin{tabular}{lcc}
\hline & Vitamin K & Control \\
\hline$n$ & 6 & 6 \\
Male:female & $2: 4$ & $3: 3$ \\
Gestational age $(\mathrm{wk})$ & $39.5 \pm 1.8$ & $40.4 \pm 0.7$ \\
Birth wt $(\mathrm{g})$ & $3338 \pm 608$ & $3817 \pm 299$ \\
Apgar score at $5 \mathrm{~min}$ & $8.8 \pm 1.2$ & $9.7 \pm 0.5$ \\
Arterial cord blood $\mathrm{pH}$ & $7.27 \pm 0.03$ & $7.29 \pm 0.09$ \\
Age at venipuncture $(\mathrm{h})$ & $24.6 \pm 0.4$ & $27.8 \pm 5.8$ \\
\hline
\end{tabular}

\section{RESULTS}

The vitamin $\mathrm{K}_{1}$ concentrations and the number of SCE and CA of each subject are presented in Table 2. SCE results are missing for subjects 4 and 8 because of bad growth of BrdU cultures. Less than 20 mitoses were suitable for SCE analysis. Conventional growth was adequate and chromosome aberrations were counted. During determination of vitamin $K_{1}$ in subject 4 , a technical error was encountered. Because of the small volumes of serum available from the neonates, the procedure could not be repeated.

Twenty-four $\mathrm{h}$ after injection of $1 \mathrm{mg}$ vitamin $\mathrm{K}_{1}$, plasma levels ranged from 114.6 to $1150.5 \mathrm{ng} / \mathrm{mL}\left(255\right.$ to $2555 \times 10^{-9}$ M). Vitamin $K_{1}$ concentrations in the supplemented group were raised some 5000 -fold as compared with the control group ( $p=$ 0.006 ). In two subjects of the control group, the vitamin $\mathrm{K}_{1}$ concentration was not even detectable. Because of differences in volume of serum available, the detection limit ranged from 0.045 to $0.198 \mathrm{ng} / \mathrm{mL}$ in these samples.

In the vitamin $\mathrm{K}$-supplemented group, the mean number of SCE was $8.88 \pm 1.22$ per metaphase compared with $9.05 \pm 1.14$ in the control group. The groups did not differ significantly $(p$ $=0.82$ ).

When the total number of chromosome and chromatid breaks as well as gaps was taken into account, a mean number of 3.00 $\pm 2.61 \mathrm{CA}$ per 100 mitoses was detected in the vitamin $\mathrm{K}$ group In the control group a mean number of $2.50 \pm 1.87$ per 100 mitoses was found (NS, $p=0.71$ ). When gaps were excluded, the mean numbers amounted to $1.50 \pm 1.05$ and $2.50 \pm 1.87$, respectively. Still, no significant difference was present $(p=$ $0.28)$.

\section{DISCUSSION}

As would be expected, $24 \mathrm{~h}$ after the intramuscular administration of $1 \mathrm{mg}$ vitamin $\mathrm{K}_{1}$ serum concentrations vitamin $\mathrm{K}_{1}$ were extremely high, the mean being $536 \mathrm{ng} / \mathrm{mL}$. This finding is in accordance with the mean levels of $444 \mathrm{ng} / \mathrm{mL}$ reported by McNinch et al. (10) and of $348 \mathrm{ng} / \mathrm{mL}$ by Lucock et al. (11). McNinch et al. (10) detected a peak level of $1781 \mathrm{ng} / \mathrm{mL}$ after $12 \mathrm{~h}$. This shows that the blood lymphocytes in the vitamin $\mathrm{K}$ group certainly have been exposed to extremely high levels of vitamin $\mathrm{K}$ before sampling. Previous studies have shown that the plasma level declines rapidly (12).

Several short-term mutagenicity test systems have been developed to identify agents that can adversely affect the genetic material of cells (The American Industrial Health Council, 13). This property may indicate the potential for a number of adverse effects, one of which is carcinogenicity. There is a clear and justifiable rationale for the use of genetic toxicology assays, but they are less than perfect. Accuracy, which is a combination of sensitivity and specificity, is about $60 \%$. Therefore, one assay will be insufficient $(13,14)$. The Ames/Salmonella typhimurium assay is the test most commonly used for evaluation of chemicals in vitro (15). Vitamin $K_{1}$ was not mutagenic in this test (16). A negative Ames test, however, does not exclude carcinogenicity, inasmuch as a negative predictive value of only $51 \%$ was calculated (14). In other words, performance of an Ames test alone is inadequate to determine whether vitamin $\mathrm{K}_{1}$ is genotoxic. Moreover, Israels et al. (2) did report an increase of SCE in lymphocytes after in vitro and in vivo exposure to vitamin $\mathrm{K}_{1}$. In vitro exposure was analyzed in cultured lymphocytes of human placental blood and adult female blood with added vitamin $\mathrm{K}_{\mathrm{i}}$ at a concentration of $1 \times 10^{-6} \mathrm{M}(450 \mathrm{ng} / \mathrm{mL})$. Consequently, the lymphocytes that were stimulated to replicate by phytohemagglutinin were exposed for at least $48 \mathrm{~h}$ to a high concentration of vitamin $\mathrm{K}_{1}$. This is quite different from in vivo situations, where high concentrations of vitamin $\mathrm{K}_{1}$ are only temporary and lymphocytes normally do not divide. In vivo exposure was tested in fetal sheep in utero given $1 \mathrm{mg}$ of vitamin $\mathrm{K}_{1}$ i.v. SCE were 
Table 2. Number of SCE and CA in metaphases of cultured lymphocytes of newborns who did or did not receive $1 \mathrm{mg}$ vitamin $K_{1}$ intramuscularly after birth

\begin{tabular}{|c|c|c|c|c|c|c|c|}
\hline \multirow[b]{2}{*}{ Subject } & \multicolumn{3}{|c|}{$\mathrm{SCE}$} & \multicolumn{3}{|c|}{$\mathrm{CA}^{*}$} & \multirow{2}{*}{$\begin{array}{c}\text { Vitamin K } \\
(\mathrm{ng} / \mathrm{mL})\end{array}$} \\
\hline & $n \dagger$ & Mean & $\mathrm{SD}$ & Chrbr & Chrmatbr & Gap & \\
\hline \multicolumn{8}{|l|}{ Vitamin $\mathrm{K}$} \\
\hline 1 & 25 & 9.96 & 2.92 & 0 & 1 & 0 & 114.6 \\
\hline 2 & 24 & 7.96 & 2.46 & 0 & 0 & 0 & 203.9 \\
\hline 3 & 26 & 8.03 & 3.13 & 0 & 2 & 5 & 545.0 \\
\hline 5 & 20 & 10.45 & 3.68 & 0 & 3 & 0 & 443.4 \\
\hline 8 & & & & 0 & 1 & 4 & 1150.5 \\
\hline 11 & 24 & 8.00 & 2.67 & 2 & 0 & 0 & 757.4 \\
\hline Mean & 23.8 & 8.88 & 2.97 & 0.33 & 1.17 & 1.5 & 535.8 \\
\hline \multicolumn{8}{|l|}{ Control } \\
\hline 4 & & & & 0 & 2 & 0 & \\
\hline 6 & 20 & 10.30 & 2.92 & 0 & 6 & 0 & 0.188 \\
\hline 7 & 21 & 8.52 & 2.69 & 0 & 1 & 0 & $<0.045$ \\
\hline 9 & 24 & 7.80 & 2.77 & 1 & 2 & 0 & 0.130 \\
\hline 10 & 29 & 8.41 & 2.10 & 1 & 0 & 0 & 0.132 \\
\hline 12 & 25 & 10.24 & 3.20 & 0 & 2 & 0 & $<0.198$ \\
\hline Mean & 23.8 & 9.05 & 2.74 & 0.33 & 2.17 & 0 & \\
\hline
\end{tabular}

* Per subject, 100 mitoses were screened. Chrbr, number of chromosome breaks; Chrmatbr, number of chromatide breaks.

$\uparrow$ Number of cells investigated for SCE.

measured before and $24 \mathrm{~h}$ after injection. Each fetus showed an increased number of SCE after vitamin $\mathrm{K}_{1}$.

Because the aim of the present investigation was to determine whether there are indications that vitamin $\mathrm{K}$ may have genotoxic effects in the human neonate, we opted for an in vivo study in humans with the intention to reflect the clinical situation, especially because several unknown factors may hamper generalization of in vitro and animal studies to clinical practice. SCE and $\mathrm{CA}$ analyses were performed on cultured lymphocytes after exposure of the neonate in vivo. Accordingly, the vitamin will be subjected to the spectrum of activating and deactivating enzymes as far as these are developed in the newborn (17). Detoxification or formation of toxic degradation products might be different in fetal lambs as compared with human neonates. In fetal mice SCE response was found to decline with gestational age (18). Administration of mitomycin $\mathrm{C}$, a mutagen that does not require metabolic activation, and of cyclophosphamid, a drug activated by the liver into a potent alkylating agent, both resulted in a decline in SCE with gestational age. Repair capacities may vary with gestational age.

Fortunately, no carcinogenic metabolites are reported for vi$\operatorname{tamin} \mathrm{K}_{1}$. In the liver vitamin $\mathrm{K}$ is first reduced to vitamin $\mathrm{K}$ hydroquinone and subsequently oxidized to vitamin $\mathrm{K}-2,3$-epoxide. This oxidation is connected with the carboxylation reaction in which glutamic acid residues of vitamin K-dependent coagulation factors are carboxylated. Subsequently, vitamin K-2,3epoxide is converted back into natural vitamin $\mathrm{K}$ and the cycle is complete. In adults vitamin $\mathrm{K}_{1}$ is excreted in urine and bile as more polar metabolites (carboxylic acids) conjugated with glucuronic acid. An enterohepatic circulation is present (19). After supplementation with vitamin $\mathrm{K}_{1}$, urinary and fecal excretion is virtually complete after $3 \mathrm{~d}$ and amounts to about $60 \%$ of the dose (19). Whether fetal vitamin K metabolism differs from adult metabolism is unknown but conceivable.

Besides advantages, in vivo testing carries the problem that unknown confounding factors may disturb the conclusions. Age, sex, tobacco smoking, medication, and alcohol abuse may be confounders (20). In the present study these items were excluded or otherwise randomized. We were unable to detect an increase in SCE $24 \mathrm{~h}$ after the administration of $1 \mathrm{mg}$ vitamin $\mathrm{K}_{1}$ intramuscularly.

Because additional negative results were achieved in the CA analysis, which is a less sensitive but more specific short-term mutagenicity test (14), a genotoxic effect is improbable.

When the effects of supplementation with vitamin $\mathrm{K}$ are considered, not only plasma concentrations (and lymphocyte exposure) have to be taken into account. Concentrations in other tissues may differ. It might be possible that because of accumulation hepatic concentrations higher than plasma concentrations are reached. The hepatic vitamin $\mathrm{K}_{1}$ level in unsupplemented term neonates is reported to be about $1 \mathrm{ng} / \mathrm{g}$ liver (fresh weight) with a wide range (21). This is 10 -fold higher than the plasma level of about $0.1 \mathrm{ng} / \mathrm{mL}$ in our control group. Shearer et al. (21) have reported hepatic vitamin $\mathrm{K}_{1}$ concentrations $10 \mathrm{~h}$ after intramuscular administration of 0.5 to $1.0 \mathrm{mg}$ vitamin $\mathrm{K}_{1}$ of approximately $200 \mathrm{ng} / \mathrm{g}$ and after 1 to $4 \mathrm{~d}, 500-2000 \mathrm{ng} / \mathrm{g}$. These levels are comparable to the plasma levels in our supplemented group, so there are no indications that higher concentrations are reached in the liver than in the blood after a single intramuscular dose of vitamin $\mathrm{K}_{1}$.

In conclusion, as yet there is no evidence for cytogenetic toxicity due to the administration of $1 \mathrm{mg}$ vitamin $\mathrm{K}_{1}$ intramuscularly to the newborn infant.

\section{REFERENCES}

1. Matsuzaka T, Yoshinaga M, Tsuji Y, Yasunaga A, Mori K 1989 Incidence and causes of intracranial hemorrhage in infancy: a prospective surveillance study after vitamin $\mathrm{K}$ prophylaxis. Brain Dev 11:384-388

2. Israels LG, Friesen E, Jansen AH, Israels ED 1987 Vitamin $K_{1}$ increases sister chromatid exchange in vitro in human leukocytes and in vivo in fetal sheep cells: a possible role for "vitamin K deficiency" in the fetus. Pediatr Res 22:405-408

3. Latt SA, Schreck RR, Lovedays KS, Dougherty CP, Shuler CF 1980 Sister chromatid exchanges. Adv Hum Genet 10:267-331

4. Golding J, Paterson M, Kinlen LJ 1990 Factors associated with childhood cancer in a national cohort study. Br J Cancer 62:304-308

5. Buckton KE, Evans HJ 1973 Methods for the Analysis of Human Chromosome Aberrations. World Health Organization, Geneva

6. Gebhart E 1981 Sister chromatid exchange (SCE) and structural chromosome aberration in mutagenicity testing. Hum Genet 58:235-254

7. Lambert WE, De Leenheer AP, Lefevere MF 1986 Determination of vitamin $\mathrm{K}$ in serum using HPLC with post-column reaction and fluorescence detection. J Chromatogr Sci 24:76-79

8. Lambert WE, De Leenheer AP 1987 Simplified post-column reduction and fluorescence detection for the high-performance liquid chromatographic determination of vitamin $K_{1(20)}$. Anal Chim Acta 196:247-250

9. Verma RS, Lubs HA 1975 A simple R banding technic. Am J Hum Genet 27:110-117

10. McNinch AW, Upton C, Samuels M, Shearer MJ, McCarthy P, Tripp JH, L'E Orme R 1985 Plasma concentrations after oral or intramuscular vitamin $\mathrm{K}_{\text {, }}$ in neonates. Arch Dis Child 60:814-818

11. Lucock M, Hartley R, Wild NJ 1987 HPLC determination of vitamin $\mathrm{K}_{1}$ in neonatal plasma following oral or parenteral supplementation with Konakion. J Liquid Chromatogr 9:191-203

12. Widdershoven $J$, Lambert $W$, Motohara K, Monnens L, De Leenheer A. Matsuda I, Endo F 1988 Plasma concentrations of vitamin $\mathrm{K}_{1}$ and PIVKA- 
II in bottle-fed and breast-fed infants with and without vitamin $\mathrm{K}$ prophylaxis at birth. Eur J Pediatr 148:139-142

13. Kier LD 1988 Comments and perspective on the EPA workshop on "the relationship between short-term test information and carcinogenicity." Environ Mol Mutagen 11:147-157

14. Tennant RW, Margolin BH, Shelby MD, Zeiger E, Haseman JK, Spalding J, Caspary W, Resnick M, Stasiewicz S, Anderson B, Minor R 1987 Prediction of chemical carcinogenicity in rodents from in vitro genetic toxicity assays. Science 236:933-941

15. Ames BN, McCann J, Yamasaki E 1975 Methods for detecting carcinogens and mutagens with the Salmonella/mammalian-microsome mutagenicity test. Mutat Res 31:347-364

16. Tikkanen L, Matsushima T, Natori S, Yoshihira K 1983 Mutagenicity of natural naphtoquinones and benzoquinones in the Salmonella/microsome test. Mutat Res 124:25-34

17. Perry PE, Thomson EJ 1984 The methodology of sister chromatid exchanges.
In: Kilbey BJ, Legator M, Nichols W, Ramel C (eds) Handbook of Mutagenicity Test Procedures. Elsevier, New York, pp 495-529

18. Kram D, Bynum GD, Senula GC, Bickings CK, Schneider EL 1980 In utero analysis of sister chromatid exchange: alterations in susceptibility to mutagenic damage as a function of fetal cell type and gestational age. Proc Natl Acad Sci USA 77:4784-4787

19. Shearer MJ, McBurney A, Barkhan P 1974 Studies on the absorption and metabolism of phylloquinone (vitamin $\mathrm{K}_{1}$ ) in man. Vitam Horm 32.513 542

20. Wulf HC 1990 Monitoring of genotoxic exposure of humans by the sister chromatid exchange test. Methodology and confounding factors. Dan Med Bull 37:132-143

21. Shearer MJ, McCarthy PT, Crampton OE, Mattock MB 1988 The assessment of human vitamin K status from tissue measurements. In: Suttie JW (ed) Current Advances in Vitamin K Research. A Steenbock Symposium. Elsevier, New York, pp 437-452

\section{Announcement}

\section{American Board of Nutrition}

\section{Examination}

The next certifying examination of the American Board of Nutrition will be administered on May 1 and 2, 1992 in conjunction with the Annual Meeting of The American Society for Clinical Nutrition in Baltimore, MD.

Individuals with a doctoral degree (M.D., Ph.D., or equivalent) and appropriate nutrition background are eligible to take the examination. M.D. candidates must be certified by a primary board recognized by the American Board of Medical Specialties and have completed at least 2 years of appropriate nutrition training at the time of the examination.

Deadline for receipt of academic records and sponsoring letters is January 2, 1992.

For more detailed information, write to: American Board of Nutrition, 9650 Rockville Pike, Bethesda, MD 20814. Telephone: (301) 530-7110. 